\title{
A comparative study of the semantics and pragmatics of enfin and finalement, in synchrony and diachrony ${ }^{1}$
}

\author{
MAJ-BRITT MOSEGAARD HANSEN
}

University of Copenhagen

(Received September 2004; revised March 2005)

\begin{abstract}
This article compares and contrasts two related adverbs, enfin and finalement, in synchrony and diachrony. Both are polysemous in contemporary French, and largely intersubstitutable in many contexts. However, the functional range of enfin is much greater than that of finalement. Evidence is presented for the existence of a division of labour, such that speakers seem to favour finalement for more 'literal' functions, i.e. for the expression of temporal sequence, whereas enfin is preferred for more abstract, non-propositional functions. This is attributed to the respective formal properties and degree of grammaticalisation of the two expressions, which can also explain why enfin has developed a vastly greater range of abstract, non-propositional functions than finalement. The argument is supported by diachronic evidence that the functional extension of enfin has gone hand in hand with significant changes in the formal status of the expression, while functional extension of finalement stops at approximately the time when enfin begins to expand its range.
\end{abstract}

\section{INTRODUCTION}

In this article, I will compare and contrast the two adverbs enfin and finalement from the point of view of both their synchronic uses and their diachronic evolution, the emphasis being on finalement. The two items share a partially common - and still transparent - etymology of a temporal nature, and both are polyfunctional in contemporary French of both the spoken and the written variety, having, on the one hand, a propositional, temporal sense, and, on the other hand, various nonpropositional senses, several of which can be analysed as fulfilling discourse-marking functions. They are, moreover, largely intersubstitutable in some - although far from all - contexts. One prominent difference between them, however, is that the range of possible readings of enfin is much greater than that of finalement.

Section 2 of this article will summarise previous research on the synchronic meanings and functions of each of the two markers, and section 3 will delve

${ }^{1}$ I wish to thank Lene Schøsler for helpful comments on an earlier version of this manuscript.

Needless to say, she is not responsible for any shortcomings that may remain. 
into the diachronic trajectory of finalement in particular. Section 4 compares the synchronic semantics and pragmatics of the two markers. Finally, section 5 considers the morphological and phonological properties of both expressions, and briefly considers some differences between their uses in contemporary spoken French. The article is concluded with a few recommendations for methodology in discoursemarker research.

A closer comparison between the two markers is of interest among other things because, as noted above, enfin is significantly more polyfunctional than finalement. Indeed, in a recent study of the diachronic evolution of enfin (Hansen, 2005), I identified no less than I4 different uses of that adverb. While it is possible to represent these various uses in a single sense network, where each individual use is shown to be derived from at least one other previously existing use, mainly by processes of metonymic extension, some of them are nevertheless separated by several derivational steps. When considering such pairs of uses in isolation, the semantic commonalities between them are therefore less than fully transparent, cf. the contrast between the purely temporal reading of the adverb in (I) and its topic-closing, mitigating function in (2):

(I) Pierre a éteint la télé, il s'est brossé les dents, il s'est déshabillé, et enfin il s'est couché.

(2) Peut-être que tu devrais en parler avec Pierre. Enfin, tu fais ce que tu veux ...

Finalement, on the other hand, appears to have only three basic uses, among which there seem, intuitively, to be fairly close semantic and pragmatic ties, as for instance between the temporal use in (3) and the concluding use in (4):

(3) Les questions qui restaient en suspens étaient finalement renvoyées à la direction.

(4) La scénographie était plutôt nulle, mais la mise en scène n'était vraiment pas mal. Finalement, on a passé une bonne soirée.

At the same time, and no doubt at least partially due to its significantly wider range of uses, enfin occurs with vastly greater frequency than finalement in contemporary French of both the spoken and written variety. Thus, the electronic corpus known as Frantext yields 35,648 tokens of enfin from a total of I,534 twentieth-century written texts representing a wide range of genres, ${ }^{2}$ but only 3,536 tokens of finalement, while a search of six different spoken-language corpora totalling a little over four hours of naturally occurring dialogue between native speakers ${ }^{3}$ resulted in II 7 tokens of enfin, as compared to a mere I9 tokens of finalement.

2 The Frantext database as a whole contains approx. 3,500 works written between I 500 and the present day. Eighty per cent of the texts are of a literary nature, while 20 per cent are of a technical, scientific nature.

3 The corpora in question comprise one radio debate with four participants, two radio debates with five participants each, one telephone conversation, and two face-to-face conversations, each with two participants. I thank Mary-Annick Morel of the Université de Paris III for allowing me access to these corpora, which were recorded and transcribed by her research group on spoken French. 
Finally, the diachronic development of the two markers shows interesting differences. As shown in Hansen (2005), enfin is amply attested in the Old French texts represented in the Base de français médiéval (BFM) data base. ${ }^{4}$ For several hundred years, it remains uniquely associated with a purely temporal, truthconditional sense, in which it denotes that the state-of-affairs in its scope constitutes the last in a sequence, just as in the contemporary example in (I) above. Although conversational implicatures of various kinds may, of course, be triggered by this use in specific contexts, clearly distinct new uses are not found until the late sixteenth century, after which enfin embarks on a gradual process of semantic and pragmatic extension lasting up to the twentieth century.

As will be more fully described below, finalement, on the other hand, hardly appears in the BFM corpus before the Middle French period, and it completes its semantic-pragmatic trajectory in the space of only two hundred years, coming to a halt around the time when enfin is just beginning to develop any extended senses beyond the original, purely temporal one.

The hypothesis of the present article is that the substantially different phonological and morphological make-up of the two items, combined with the fact that enfin, but not finalement, has undergone a process of grammaticalisation, may not only help to explain the observed time-lag in the development of enfin, but also why the latter is ultimately a better candidate for extensive functional change than finalement.

\section{PREVIOUS RESEARCH}

\section{I Enfin}

A number of authors have proposed descriptions of the meaning(s) and uses of enfin. Due to limitations of space, I will take the liberty, in the present section, of referring exclusively to my own recent article (Hansen, 2005). References to, and a critical review of, preceding studies can be found in that article.

In my study, which has a strong diachronic slant, I follow Geeraerts' (I997) prototype approach to meaning, and I suggest that present-day enfin has three 'prototype' senses, from each of which several peripheral uses can be derived. The prototype senses are, respectively, the temporal sense exemplified in (I) above; a non-truth-conditional 'synthesising' sense, in which enfin marks (a part of) an utterance that sums up the previous discourse, formulates it more pithily, or draws a conclusion from it (cf. ( 5 ) below); and a 'repair' sense, in which it marks the discourse in its scope as constituting a corrective reformulation of some aspect of the previous discourse (cf. (6)).

(5) Cédric est grand, beau, intelligent, spirituel - enfin, parfait, quoi!

${ }^{4}$ The BFM is another searchable internet/CD-ROM corpus containing 48 texts in verse, and 29 prose texts written between 800 and I 600 . 
(6) Tout le monde est venu à la soirée. Enfin, tous ceux qui n'étaient pas partis en vacances.

I show that these senses can be linked metonymically ${ }^{5}$ in a polysemy network having the temporal sense as its point of departure. Thus, the synthesising sense, which first occurs in the second half of the sixteenth century, can be derived from the temporal one by a figure-ground shift (cf. Waltereit, to appear) licensed by an invited inference of structural parallelism between narrative discourse, where temporal enfin is prototypically found, and expository discourse, where the synthesising use is more likely to occur.

The inference in question is grounded in the fact that narratives are typically constructed in such a way that the important climactic event is presented as the last one to occur, whereas relevant, but less important events tend to be constructed as temporally prior to, and preparing, the climactic event (cf. Labov and Waletzky, I967: 33). At the same time, saving the narration of the climactic event for last is a common floor-holding strategy in narrative discourse (cf. Sacks, I995: 222ff). In a similar fashion, a synthesis or conclusion is the most important element of a piece of expository discourse. All things being equal, hearers will therefore be prone to infer that a statement occurring at the end of some stretch of expository discourse constitutes a synthesis of, or conclusion from, the preceding elements. In the temporal use of enfin, lastness can be seen as the figure, the property that is being focused on, while the importance of the event to the discourse as such is backgrounded. Conversely, in the synthesising use, the rhetorical importance of the marked utterance is highlighted, while the fact that it occurs last in the exposition is backgrounded.

The repair sense, which is not unequivocally attested in my diachronic data until the nineteenth century, can be related metonymically to the synthesising sense, in as much as a synthesis of previous discourse will normally constitute a restatement of what has already been said in a different form.

A plausible motivation for speakers to use enfin in this way is to save face by masking a reformulation of an unclear, and possibly even incorrect, statement as a synthesis. If correct, this would make the extension of the synthesising sense of enfin to repair contexts an instance of rhetorical overuse of a marker (cf. Waltereit, to appear) whereby a new figure-ground shift is effected, the reformulation, which is backgrounded in the synthesising use, being foregrounded in the repair use. The temporal sense of enfin can also be argued to persist in, and to have provided some motivation for, the repair use, given that the host utterance or utterance part constitutes the final formulation of the idea in question.

As noted above, this presentation is grounded in the prototype approach to linguistic categories set out in Geeraerts (1997). This approach belongs to what Kleiber (I990: ch. IV) calls the 'extended' version of prototype theory. This implies that the three senses of enfin cannot be defined by means of single sets of necessary

${ }^{5}$ The term is used lato sensu, following Traugott and Dasher (2002: 28f). 
and sufficient conditions for membership: instead, the internal structure both of each of the three senses identified, and of the overarching category comprising all the various senses of the lexeme enfin, is seen as consisting in clustered and overlapping readings.

This entails, as is also implied by the account of the probable metonymic links obtaining between the three prototype senses mentioned above, that the different senses inventoried in the marker's semantic network are not seen as independent of one another. Diachronically, it is clear that they are highly dependent, in as much as more recent senses must be assumed to be derived from earlier ones. Synchronically, it is also highly likely that they are linked to a greater or lesser degree in the minds of the language users, given that some of the more peripheral uses of enfin seem to be derivable from two different prototypical senses.

Thus, for instance, enfin has a 'listing' use, in which it marks the element in its scope as being the last in a particular discourse sequence. (7) exemplifies the listing use of enfin in connection with a series of speech acts of a similar type, namely (presumably rhetorical) questions.

(7) Nos soldats n'ont-ils plus de bras pour placer des canons de 4, de 8 et même de I 2 qui pourraient servir un jour de bataille ? Nos généraux de division n'ontils aucuns chevaux en réserve ? Enfin n'avons-nous donc plus de baïonnettes? (Claude Simon, Les Géorgiques, I98 I - from Frantext)

The listing use develops at approximately the same period as the synthesising use. Like the latter, it can be derived from the temporal use in (I) by metonymy: all things being equal, in a narrative, the last relevant event to occur in the real world will, as I observed above, tend to be recounted in final position in the narrative sequence. Whereas the temporal use of enfin profiles the chronological position of the real-world event, the listing use instead profiles the discourse position of its host utterance, backgrounding the real-world chronology to the point where the actual order of events becomes immaterial. Thus, the utterance of (8) does not entail that Marc necessarily obtained his doctorate in psychology last - that degree may simply be the last one to occur to the speaker.

(8) Marc possède plusieurs doctorats: de linguistique, de philosophie, de littérature, et enfin de psychologie.

What this means, of course, is that, like synthesising enfin, listing enfin is nontruth-conditional and scopes the speech act rather than the proposition. To that extent, it could be argued to be as closely related to the synthesising prototype as to the temporal one. In Hansen (2005), I classify it as a peripheral instance of the temporal prototype. This is justified in at least two respects: first, it resembles the temporal, but not the synthesising, prototype, in not operating any kind of transformation of the contents of the preceding discourse; and second, both temporal and listing enfin can be preceded by the coordinating conjunction et, 
which is not normally the case for synthesising enfin. ${ }^{6}$ Both observations suggest that the mental model of the discourse structure which the hearer is encouraged to construct, is marked as a hierarchical one by the presence of synthesising enfin, whereas the former two uses rather mark linear discourse structures.

As such, my classification of listing enfin with the temporal prototype can be said to privilege pragmatics over semantics, if the latter is taken - as it traditionally is - to be centrally concerned with the truth-conditional content of utterances. However, I prefer to define semantics as concerned with the coded context-independent content of utterances and their constituent parts; whether or not such content is truth-conditional or not is simply one descriptively relevant aspect of meaning among others.

Last, but not least, the existence of synchronic links between senses means that the use of conditions for meanings that are diachronically earlier may come to be influenced by later extensions. An example of how the use of synthesising enfin appears to be thus coloured by its diachronically later repair use will be given below.

\subsection{Finalement}

As for finalement, to my knowledge, few studies exist that deal in any kind of detail with the semantics and pragmatics of this marker, and none that consider the diachronic development of its various senses. Apart from some brief remarks by Ducrot et al. (I980: I55), analyses of the marker can be found in Schelling (1982, I983), Roulet (1987) and Franckel (1989). With the exception of one aspect to which I will return below, these accounts are by and large compatible, Schelling's (I982) being the fullest. This author distinguishes two uses of the adverb, a 'chronological' use, and a 'conclusive' use.

In the former, finalement is said to mark the last of a succession of facts, where the term 'facts' covers both real-world events, as in (9), and discourse 'events' such as the succession of evaluative statements in (IO):

(9) Il sonna à la porte, attendit un moment, et finalement s'en alla. (Schelling's (3))

(Iо) Ce que je pense du film? Eh bien, tout d'abord les images sont superbes, les acteurs sont bons, et finalement le scenario est drôle. (Schelling's (4))

${ }^{6}$ In the following example, which is among the very earliest instances of the synthesising use, enfin is, in fact, preceded (albeit not immediately) by et. This suggests that the borderline between the listing and the synthesising use is a fine one, and that, rather than developing directly out of the propositional temporal use, synthesising enfin may have its origin in the listing use:

(i) ... les amoureux se courroussent, se réconcilient, se prient, se remercient, s'assignent et disent enfin toutes choses des yeux ... (Michel de Montaigne, Essais, vol. I, I 592, from Frantext)

This supports Geeraerts' (I997: I I) assumption that different senses of a single lexeme shade into one another, and are not strictly separate. 
In both cases, finalement marks, according to Schelling, an asymmetric relationship between the 'facts' in question, this relationship taking the form of an assigned order of progression or of an assigned order of priority, respectively.

In its conclusive use, finalement is analysed as articulating a minimum of three discourse units: two opposing arguments, ${ }^{7}$ and a conclusion supported by the second of the two arguments, which is thus seen as the stronger one. Thus, in (II), the fact that the speaker spent the weekend in the mountains with Pierrot must, according to Schelling (op.cit.: 76) be interpreted as an argument in favour of her having had a good time there, while the fact that it snowed all day Sunday must be interpreted as an argument in favour of the opposite conclusion, which is implied by the finalement-marked utterance:

(i I) J'ai été à la montagne avec Pierrot, dimanche il a neigé toute la journée, finalement $\mathrm{j}$ 'aurais mieux fait de rester à la maison. (Schelling's (6))

Only in the conclusive use is finalement a discourse connective, on Schelling's analysis (op.cit: 69). To determine the marker's status, she employs three syntacticsemantic criteria, namely whether it can fall under the scope of negation and interrogation, and whether it can be embedded. Thus, finalement would be a connective in its conclusive use in (I2), but not in its chronological use in (I 3 ):

(I2) *[Il n'est pas vrai que/Est-ce que/Jean m'a rapporté que] Pierre est allé au cinéma, puis voir Julie, finalement il aurait dû rentrer plus tôt. (Schelling's (I))

(I3) [Il n'est pas vrai que/Est-ce que/Jean m'a rapporté que] Pierre est allé au cinema, puis voir Julie, finalement il est rentré très tard. (Schelling's (2))

There are two problems with this analysis, however. One is that 'conclusive' finalement can in fact be, and often is, embedded in actual language use, cf. the authentic example (I4). Indeed, there appears to be little empirically-grounded reason to assume that discourse connectives in general cannot be embedded, so that criterion is inconclusive at best.

(I4) Il dit que finalement, cette histoire de tatoueur, c'est pas si ringard. On peut en tirer quelque chose. (Evane Hanska, Les amants foudroyés, I984, from Frantext)

Second, if we apply Schelling's tests to the 'chronological' use, we are forced to conclude that the two tokens of finalement in, respectively, (9) and (Iо) above cannot be instances of the same basic use, as the oddness of ( 15 ) shows. To the extent that it is at all possible for 'discourse-event chronological' finalement to fall under the scope of negation or interrogation, the embedded sentence must be understood as echoing somebody else's choice of words, which means that

${ }^{7}$ Schelling does not say so, but in view of examples such as the following, we must assume that one or both of these arguments may, in actual practice, remain implicit:

(i) Jeanne.// I6 juin.// Finalement, j'ai passé une très bonne soirée, hier au 'Chapon Grisouillis'. (Françoise Dorin, Les vendanges tardives, I997, from Frantext) 
the focus of the negation/interrogation would, in that case, be metalinguistic in nature. Conversely, embedded under a speech act verb like rapporter, 'discourseevent chronological' finalement will strongly tend to be read parenthetically, as expressing the reporting speaker's point of view, as opposed to that of the reported speaker. In other words, 'discourse-event chronological' finalement appears to be no less a pragmatic connective than 'conclusive' finalement.

(I5) ??[Il n'est pas vrai que/Est-ce que/Jean m'a rapporté que] tout d'abord les images sont superbes, les acteurs sont bons, et finalement le scenario est drôle.

This is further supported by the fact that, while the 'real-world-event chronological' finalement exemplified in (9) is truth-conditional, 'discourse-event chronological' finalement is not. From a purely truth-conditional point of view, it makes no difference whether one asserts (IO) or the modified version in (I6). (I7), on the other hand, makes a very different (and rather unlikely) assertion about the world than (9) does.

(I6) Ce que je pense du film? Eh bien, tout d'abord, les acteurs sont superbes, le scenario est drôle, et finalement les images sont superbes.

(I7) Il attendit un moment, s'en alla, et finalement sonna à la porte.

Further, the contrast between (9) and (I7) suggests that Schelling (op.cit.: 70) is wrong to claim that 'chronological' finalement presents the order of the events recounted as established by the speaker. That is only the case in the 'discourseevent' use, where a speaker may, indeed, choose freely between, for instance, (Iо) and (I6), depending only on her communicative aims in the specific context of utterance. $^{8}$

Thus, by using Schelling's own criteria, we end up with at least three, rather than just two, clearly distinct uses of finalement: a purely temporal, propositional use corresponding to (9), a metadiscursive, non-propositional 'listing' use corresponding to (IO), and an argumentative, non-propositional use in which finalement marks a conclusion, corresponding to (I I). Her bi-partite description can, however, be maintained in a prototype approach to lexical semantics of the type described above in connection with enfin, given that temporal and 'listing' finalement are related in essentially the same manner as the corresponding uses of enfin.

With respect to the argumentative use of finalement, Schelling's contention that it marks its host utterance as a conclusion supported by the second of two opposing arguments (a hypothesis she essentially takes over from Ducrot et al., I980: I 55) is called into question by Roulet (I987), who describes the marker as essentially reformulative.

${ }^{8}$ Speakers may, of course, present the chronological order of real-world events in whichever way they please, including factually incorrect ones, but in the latter case, they expose themselves to (interactionally unmarked) accusations of untruthfulness on the part of their addressees, something which is manifestly not an option where the ordering of discourse events is concerned. 
On Roulet's analysis, reformulative connectives mark changes in discourse perspective. As such, they either background or invalidate the previously adopted perspective. Reformulative finalement is characterised by the fact that it does not specify what gave rise to the new perspective, that it does not indicate precisely which elements of the previous discourse are included in the backgrounded or rejected perspective, but that it does indicate that the change in perspective operated is one that has a temporal dimension (op.cit.: I2O). Although, indeed, the marker frequently articulates opposing elements, this is not a criterial feature of its use, as evidenced by the authentic corpus example in (I8), where none of the preceding statements seem in any way to contradict the concluding evaluation of Bashung's style.

(I8) Fin des années septante, Bashung se trouve enfin: côté musique et voix, il s'inspire de Lou Reed et de J.-J. Cale; côté textes, il lance avec son compère Boris Bergman ce que l'on pourrait appeler l'humour sordide sentimental, au service d'un scepticisme absolu. Surtout, il fait rendre gorge à la syntaxe et aux mots français. [ . . .] Finalement, le style Bashung se résume en une phrase: hisser le n'importe quoi au niveau d'art majeur. (from Roulet op.cit.: I29)

Roulet's example does not appear to be a nonce occurrence, as I have found similar examples in my data, including (I9) below (from a conversation about Ancient Egypt). Thus, we are forced to conclude that the use of conclusive finalement does not necessarily presuppose the presence in previous discourse of arguments oriented towards opposite conclusions.

(i9) A. . . .c'est extraordinaire ça, déjà ils avaient déjà trouvé e comment on pouvait gaver les oies, ils savaient \&les gaver hein $\& \&^{9}$

B. \&mais y a des recettes $\& \&$ de cuisine apparemment ils faisaient $\S$ des choses

A. §oui

B. qui étaient bonnes \&y avait\&\& les fameux ragoûts d'oie par exemple ça devait $\S$ pas être mauvais $\S \S$

A. \&e on l'a vu dans\&\& §on l'a/ on l'a vu§§ elle nous a montré \&dans dans/

B. \& oui

A. je sais plus dans quel temple y avait des recettes $§$ hein

B. $\S \mathrm{m}$

A. y avait des recettes de cuisine inscrites (h) puis y avait dans les laboratoires des temples des recettes \&e

9 Transcription conventions:

$\&-\& \&$ and $\oint-\S \S$

, , -

(h) overlapping talk

short, medium-length, and long pause, respectively

abrupt halt in the speech stream

hearable in-breathy

vowel lengthening 
B. $\& m$

A. pour les médicaments e:t (h) pour fabriquer leurs §produits on a vu tout ça hein $\S \S$

B. §oui parce que y avai:t e $\S$ au:

A. bon elle nous les a pas vraiment traduits mais elle nous a dit bon à ces endroits-là \&avec ces hiéroglyphes

B. \&m

A. et puis (h) y avait les dessins et cetera bon ben ça donnait de:s des idées, de ce qu'ils savaient faire quoi /-/ ça on l'a vu

B. ils semblaient avoir finalement une: une nourriture assez variée (VE, 48-49)

In sum, although the authors mentioned in this section, in particular Schelling, have made important headway, a definitive analysis of the semantics and pragmatics of finalement is still lacking. The following sections will attempt to bring us one step closer to such an analysis, partly by delving into the diachronic evolution of the marker, and partly by explicitly contrasting its uses with those of enfin.

\section{THE DIACHRONIC EVOLUTION OF FINALEMENT}

The earliest examples of finalement in the Base de français médiéval go back to the late twelfth century. In Old and Middle French, the marker is almost always spelled finablement, but as there was no standardised orthography at the time, and as I have not been able to detect any differences in meaning or use of finalement vs finablement, I will henceforth treat the two as synonymous. ${ }^{10}$

In Old French, there are only three examples, all from the same source, Li Quatre livre des Reis, a work of prose written ca. I I90 in Anglo-Norman, a dialect which differs substantially from other Old French dialects in a number of ways. No further examples of the adverb are found until the latter half of the fourteenth century, i.e. in early Middle French. For the entire Middle French period, only thirty-four examples, from a mere six different works of prose, are attested in the BFM. As already noted in section I above, the entrenchment of finalement, if not its first appearance, thus appears to be significantly more recent than that of enfin, which is frequently attested in Old and Middle French, and in both verse and prose texts, from the middle of the twelfth century onwards.

The oldest tokens of finalement all instantiate the temporal, truth-conditional use of the adverb, in which it marks the last event in a narrative sequence. As we would expect, it co-occurs massively with the passé simple, as opposed to the imparfait, and also with a variety of other temporal adverbials and conjunctions, as in (20):

10 Indeed, a similar type of variation is found in the case of enfin, which throughout both Old and Middle French may be written in either one or two words, as either en fin or an fin, and in many cases even with an intervening definite article (en la fin) seemingly with no semantic or pragmatic difference, cf. Hansen (2005). 
(20) Or aviserent li François une autre maniere d'asaut, et fist on armer .I. jour tous ceuls del hoost; et qant il furent armé, li signeur ordonnerent que chil de Toulouse, de Carcasonne, de Biauqaire et tout li home des senescaudies desus dittes qui la estoient, feissent assaut dou matin jusques a midi, et chil de Bighorre, de Roergue, de Qersi et d'Aginois, a lor retraicte, jusques a viespres, et chils qui premierement poroit conquester le pont averoit cent esqus. $\mathrm{Li}$ dus de Normandie, pour mieuls furnir cel assaut, fist venir et asambler sus la riviere grant plenté de nefs et de calans. Li plusieurs entrerent dedens pour passer la ditte riviere, et li auqun passerent au pont que il avoient fait. Qant chil dou chastiel veirent l'ordenance del assaut, si furent tantos apparilliet pour desfendre. // Lors commença uns trop plus fiers assaus que il n'i euist encores eu. Qui veist la gens abandoner vies et corps, et aprocier le pont pour la convoitise des esqus gaegnier, et presser l'un sus l'autre ensi que par envie, et qui veist aussi cheuls dou chastiel euls desfendre vassaument, de toutes ces coses il se peuist grandement esmervillier. Finablement, au fort de la besogne, auqun appert compagnon se missent en un batiel desus la riviere, et vinrent desous le pont et jetterent grans gros cros et haves de fier au dit pont leveis, et puis tirerent si fort que de force il rompirent les chainnes qui le pont portoient et tenoient, et l'avalerent jus par force. (Froissart, Chroniques, pp. 666f.) ${ }^{11}$

From the very beginning, temporal finalement is frequently found in contexts where at least some of the narrated events preceding the marked final event would seem to suggest a different outcome, for instance in the case of (2I), where one might have expected that the Duke of Brabant would succeed in his ploy to protect the Count d'Artois from the King's hatred.

(2 I) Car sitretos que les nouvelles furent venues jusques a lui, il [le roi de France] envoia tantos lettres et messages deviers le duch de Braibant, et li manda et conmanda que il mesist hors de son pais messire Robert d'Artois, ou il n'averoit piour ennemi de lui. Qant li dus de Braibant oi ces manaces, si se conmença a doubter, et rescripsi au roi que volentiers il feroit ce que il li mandoit. Et retournerent li message a Paris deviers le roi, et li baillierent les lettres dou duch de Braibant. Li rois les ouvri et lissi, et se apaisa sur ce que il trouva dedens. Li dus de Braibant se dissimula de ces premieres lettres et quida le roi mener par aultre voie. Et presta a messier Robert d'Artois le chastiel d'Argentuel, jusques a tant que on veroit conment il rois se vodroit maintenir de celle haine. // Finablement li rois le sceut, qui partout avoit ses espies, ... (Froissart, Chroniques, p. 199)

Indeed, in several instances, the final event is explicitly marked as occurring in spite of something else, by the use of concessive adverbials or conjunctions:

(22) Li rois d'Engleterre et ses consauls ignoroient de toutes ces coses, mais grans parlemens et assamblees sus li dit homage furent en celle saison en Engleterre.

11 In this and the following examples, // marks the begining of a new paragraph. 
Et i sejournerent li desus nonmé prelas et barons envoiiés dou roi de France tout l'ivier et jusques a l'issue dou mois de mai ensievant, que il ne pooient avoir nulle response. Toutefois, quoique il fust detriiet, finablement li rois d'Engleterre, par l'avis de ses previleges asquels il ajoustoit grant foi, fu consilliés de escrire ensi letters patentes seelees de son grant seel, ... (Froissart, Chroniques, pp. I9If.)

It seems plausible that examples of the type in (2I)-(22) may have helped pave the way for the conclusive sense of finalement to evolve, given that, as we saw above, that sense is overwhelmingly found in contexts where some part of the preceding discourse seems to point to the opposite conclusion from the one marked by finalement. Indeed, in example (23), finablement is very close to instantiating its modern-day conclusive sense. In this example, which is some 80 years younger than (20)-(22), the host sentence is introduced by the adversative/concessive conjunction mais, and the final event marked is, moreover, a negative one, which, arguably, gives it a timeless quality. Still, the conclusive sense of the adverb is not unambiguously attested in my data until the mid-sixteenth century, cf. (24). The mechanism of extension was most likely the same sort of metonymical figure-ground shift that was claimed, in section 2. I above, to be responsible for the extension of temporal enfin to synthesising uses, and which I assumed was based on a structural parallelism between narrative and expository/argumentative discourse.

(23) Et pareillement, de la partie du roy d'Angleterre y estoient, à tout povoir souffisant, messire Guillaume de Laboulle, conte de Suffort, maistre Adam Mollaine, garde du privé seel du roy d' Agletetre et doyen de Salsebéry, messire Robert de Roos, Thomas Hoos et aultres. Lesquelz, tous ensamble, par diverses journées se assamblèrent l' un avec l' autre. Et furent faites plusieurs ouvertures entre ycelles parties pour venir et conclure à paix généralle. Mais finablement, pour les grandes difficultés qui lors estoient entre ycelles parties, ne povoient venir ne eulx accorder à ladicte paix générale. (Enguerrand de Monstrelet, Chronique, p. 97)

(24) Secondement, ceste temeraire hardiesse de langue n'est pas sans grand péril, d'autant que espritz eschaulfez de vin sont enclins à ire et cholere, dont maintesfois yvrognerie faict trop franchement admonester et reprendre, qui engendre haine secrete. Finablement, cella est mechanicque et ne tient rien du noble ny du hardi, ... (Antoine du Saix, La touche naifve pour esprouver l'amy et le flateur inventée par Plutarque ..., I 537, from Frantext)

Finally, at the very end of the sixteenth century, we find a clear instance of the metadiscursive, 'listing' sense of finalement, reproduced in (25). Again, the mechanism of extension may be assumed to be identical to that employed in the case of listing enfin.

(25) Cherchez studieusement - et instamment les Eglises, combattez et bataillez tousjours contre le Diable avec une vraye foy en Jesus Christ et une vie de conversation honneste et heureuse. Finablement, et pour la conclusion, ma 
priere amiable que je vous fais est que vous vueilliez vous metre au lict et dormer en repos ... (Pierre-Victor Palma-Cayet, L'Histoire prodigieuse du Docteur Fauste, I 598, from Frantext)

It should be noted, however, that the listing use appears marginal in comparison with the two others, in as much as unambiguous instances of it are relatively rare in my data, most examples of list items marked by finalement being alternatively analysable as either actually chronologically posterior to the previously mentioned items (cf. (26), where, arguably, one ought to have studied, examined, weighed and explained a phenomenon prior to pronouncing judgement on it), or as constituting a more basic and/or more inclusive category than those previously mentioned items, and hence as forming a kind of implicit conclusion to, or reformulation from a different perspective of, a deliberation expressed in the discourse sequence as a whole (cf. (27), in which the first three questions all presuppose an affirmative answer to the fourth and final one):

(26) Cet art, qui consiste à étudier, à examiner, à peser, à expliquer, et finalement à juger les œuvres des autres, exige du savoir-faire . . (Gilberte et Henri Coston, L'ABC du journalisme: cours élémentaire en 30 leçons, 1952, from Frantext)

(27) Quels sont vos moyens d'existence et puis ensuite pourquoi existez-vous et puis d'abord comment existez-vous et finalement existez-vous vraiment réellement objectivement concrètement ... (Jacques Prévert, Spectacle, I95 I, from Frantext)

\section{SYNCHRONIC SIMILARITIES AND DIFFERENCES BETWEEN FINALEMENT AND ENFIN}

As we saw above, all three functions identified for finalement appear to be matched by similar uses of enfin, and in many cases, the two markers would appear to be largely interchangeable. Thus, the narrative contexts exemplified in (I) and (9) above are, in principle, compatible with the use of either adverb in its temporal sense, and, as shown in (28), individual speakers/writers may well use both adverbs within a short stretch of discourse, and with no perceptible difference in meaning:

(28) ....et les troubles lointains du ciel se dissolvaient, se résolvaient dans l'accord thématique du monde, dans cette douceur qui l'emporte enfin sur la violence, car on n'a jamais vu d'orage qui ne se soit apaisé, d'hiver qui n'ait finalement cédé au printemps, au calme apaisant de la vie. (Louis Aragon, Les voyageurs de l'imperiale, 1947, from Frantext)

Similarly, 'listing' finalement could conceivably substitute for enfin in (7), and vice versa in (I0). Finally, in (I8)-(I9), 'conclusive' finalement seems to function much like 'synthesising' enfin, which could, indeed, be substituted for finalement in (I 8).

So far, it looks as though the two adverbs were synonymous in all the uses that they share. In as much as enfin, unlike finalement, possesses a range of further uses, we might conclude that the latter lexeme was, in fact, redundant. However, there is 
evidence to suggest, on the one hand, that conclusive finalement and synthetic enfin are, in fact, not freely interchangeable, and on the other hand, that, even where they are in principle interchangeable, a 'division of labour' may exist between the two adverbs, particularly in spontaneous speech.

In respect of the first point, consider (I9), for instance. Here, the insertion of enfin in lieu of finalement appears problematic for two reasons: one is a syntactic reason, namely that the synthesising sense of enfin is not normally compatible with an utterance-medial position, contrary to the corresponding sense of finalement, which occurs in structural environments similar to that of (I9) in several of the examples in my database. The second, more important, reason why enfin is problematic here has to do with the dialogue nature of the discourse, for while finalement seems to mark an interactionally neutral conclusion from the preceding dialogue, the alternative version of B's utterance in (29) has an impatient ring to it that verges on being discourteous to $\mathrm{A}$.

(29) Enfin, ils semblaient avoir une nourriture assez variée.

This suggests that contemporary synthesising enfin not only marks a summing-up of the preceding discourse, but that, in so doing, it also marks that discourse as one that is to be replaced for some reason, for instance because it is seen by the speaker as too long-winded. Some of the earliest examples of synthesising enfin, such as that in (30), can be interpreted as carrying an implicature of this type, which most likely contributed to the appearance of the repair sense of the marker. As argued in section 2.I above, it is plausible that these two senses remain linked synchronically, and we may therefore hypothesise that the repair sense has, in turn, exerted some influence on the synthesising sense, to create the usage constraint noted in connection with (29).

(30) Et comme ils avoyent esté premierement traictez avec des gelinottes, poisons et viandes rostyes - enfin ils avoyent esté traytés passablement bien - le Docteur Fauste les consoloyt en cete façon: ... (Pierre-Victor Palma-Cayet, L'Histoire prodigieuse du Docteur Fauste, I 598, from Frantext)

This difference between synthesising enfin and conclusive finalement in modern French can then be accounted for if we assume that the two markers have different operands: while enfin is retrospective, and marks the preceding discourse as replaceable by the utterance hosting the marker, finalement is instead prospective, and marks the contents (as opposed to the utterance itself) of its host as the result of the speaker's deliberations on the matter under discussion, deliberations that are, at least in part, informed by the contents of the preceding discourse, which thus appear to have some importance in and of themselves.

Incidentally, this analysis suggests an explanation for the frequent co-occurrence of finalement with 'anti-oriented' arguments in the preceding context, for one prominent reason for deliberating a matter at some length would be precisely to attempt the reconciliation of seemingly incompatible aspects of it.

In other words, while the temporal notion of something coming to an 'end', which is contained in the etymology of both markers, persists in their uses as 
pragmatic connectives, it applies to different entities in the two cases: with enfin, the speaker attempts to put an end to the previous discourse, which may or may not be his own (cf. the analysis by Cadiot et al. 1985), and this marker therefore belongs to what Sweetser (1990) calls the speech-act level of the utterance. With finalement, on the other hand, the speaker marks the upcoming utterance as containing the end result of a thought process, and this marker thus belong rather to Sweetser's epistemic level.

\section{FORMAL PROPERTIES OF FINALEMENT AND ENFIN AND THE 'DIVISION-OF-LABOUR' HYPOTHESIS}

Once its described inventory of senses is in place by the end of the sixteenth century, finalement does not appear to undergo further changes of meaning or use in the following four centuries, right up to the present day. ${ }^{12}$ In other words, the evolution of this marker comes to a halt around the time where enfin begins to develop its non-temporal senses. Given the well-entrenched, and well-attested, assumption in lexical semantics that synonymy tends to be avoided in language, we would expect enfin to evolve in directions not already taken by finalement. Thus, Clark (1993) proposes that in both acquisition and innovation of the lexicon, language users follow a Principle of Contrast spelled out in two heuristics, which apply to the processes of language comprehension and of language production, respectively. The former heuristic enjoins hearers to assume a difference in meaning between any two different lexemes or constructions, while the latter enjoins speakers not to coin new expressions for contents that are already adequately rendered by existing ones.

There is at least circumstantial evidence that the observance of contrast has been operative in the semantic evolution of enfin. As noted above, the listing uses of both enfin and finalement first appear around the same time, and that use remains marginal for finalement. Conversely, I have found a single example in my sixteenth-century data of a use of enfin which appears closer to the conclusive use of finalement than to the synthesising use of enfin, in the sense that enfin modifies the epistemic level, as opposed to the speech-act level, of its host utterance. However, by all indications, this remains a nonce use, and a 'translation' of the example into contemporary French would favour the use of finalement instead:

(3 I) Helas, ilz pensent avoit tout;/ Mais ce tout là, qu'ilz disent leur,/ Ce n'est enfin que tout malheur:/ Nostre Tout n'est pas de la sorte. (Marguerite de Navarre, Trop, prou, peu, moins, I 544, from Frantext)

${ }^{12}$ I have found a single example, from a twentieth-century author, of finalement as a verb-modifying adverb, where it seems to mean something like 'intentionally' or 'teleologically', but this appears to be a nonce use, and it may therefore be ignored:

(i) Mais le déchiffrage de ces trames demande un long usage, un mélange peu commun de discrétion et de pénétration, et Jung insiste sans arrêt sur la nécessité de les lire finalement plus que causalement. (Emmanuel Mounier, Traité du caractère, 1946, from Frantext) 
As a matter of fact, on the assumption that the types of semantic and functional change that linguistic items can undergo are constrained by the source meanings of those items (a phenomenon known as 'persistence', cf. Hopper, I99I: 22), we may even venture the suggestion that further meaning change in finalement may have ceased around the sixteenth century because it was pre-empted by changes in enfin, in as much as the partially common etymology of the two markers would make them candidates for similar types of meaning extensions.

If such pre-emption did indeed take place, we may wonder why it was the 'late starter', enfin, which eventually won out. It seems that a plausible explanation may be sought in the formal properties of the two expressions.

As noted in Hansen (2005), enfin does not become fully grammaticalised as a particle until the sixteenth century, up until which time it is frequently found written in two words, often with a definite determiner preceding fin, suggesting that at least some language users continued to analyse it as a prepositional phrase. Whether or not these language users were the original composers of the texts in question, or whether the variable forms of the markers are due to later copyists and editors, is strictly speaking immaterial, given that the forms still provide evidence of native-speaker analyses. Moreover, whenever the marker appears as en la fin, there can be no doubt that it is felt to be a prepositional phrase. Variations may be found even within one and the same text, with no perceptible difference in meaning, cf. (32):

(32) ...l'ange bening et consolateur apparoissant à l'homme, l'espovante au commencement, le console en la fin, le rend content et satisfaict; l'ange maling et seducteur au commencement resjouist l'homme, en fin le laisse perturbé, fasché et perplex. (Rabelais, Le tiers livre, p. 463)

Finalement, on the other hand, undergoes no similar grammaticalisation process: despite the orthographic variation noted above, it is from the beginning - and it remains to this day - formally an adverb derived by the standard process of adding -ment to the feminine form of an adjective.

The syntactically complex origins of enfin may well have contributed to its retaining its literal temporal meaning longer than finalement. However, once it became fully grammaticalised, it began to lend itself to quite an advanced degree of phonological attrition: as contemporary spoken data will amply attest, enfin is very frequently reduced to 'fin, and according to A.B. Hansen (I998: I87n.), when used in non-propositional senses, both this and the full form of the marker are moreover quite frequently denasalised, being realised phonetically as $[(\mathrm{a}) \mathrm{f} \varepsilon]$.

Finalement, however, remains essentially unreduced in all contexts, which suggests a lesser degree of grammaticalisation. Furthermore, whereas the grammaticalised enfin must be considered a particle, and as such morphologically simple, finalement is morphologically relatively complex, given that it is derived from an inflected form of an adjective, final, which is itself derived from the noun fin.

Now, one very frequently made observation in discourse marker research is precisely that prototypical instances of that function category are short, 
phonologically simple, monomorphemic items, and it is well-attested that the closer a given item approaches to that prototype, the more it will tend to be endowed with a wide range of relatively abstract functions. Of the two expressions under consideration here, enfin thus appears, once grammaticalised, to be clearly the better candidate for polyfunctionality.

As for the 'division of labour' between the two expressions that I suggested above, analysis of my spoken-language data reveal that, although speakers use both enfin and finalement with a range of functions, the temporal sense accounts for 9 out of I9 examples of finalement, but only for a single example out of I I 7 of enfin. Conversely, $2 / 3$ of the tokens of enfin instantiate the repair sense of the marker, which has no counterpart among the uses of finalement. This predominance of enfin's repair sense in spontaneous spoken discourse is corroborated by results presented in Beeching (2002: I30). Moreover, whereas enfin is used at least once by almost all the speakers in my data (II/I3), the use of finalement is exclusive to only a handful of speakers (5/I3).

The observed patterns of distribution could very well be due to the different degrees of grammaticalisation of the two markers, as evidenced in their formal properties and widely diverging frequencies of occurrence in both speech and writing. Thus, the less grammaticalised finalement may favour relatively 'literal' uses due to its greater morphological complexity and phonological substance, while the frequent phonetic reduction and particle-like status of the more grammaticalised enfin would predispose its users towards more abstract, 'non-literal' functions, resulting in significantly greater frequency of occurrence across speakers, contexts and genres.

In support of this, it may be observed that, in all the attested examples I have found of the two markers occurring together in one utterance, if one is used 'literally', i.e. in its temporal sense, and the other is used in an extended sense, the 'literally' used marker is invariably finalement, as in (33):

(33) Je ne doute pas qu'ils soient finalement vaincus, mais enfin ils sont très puissants, ils ont des appuis partout. (Marcel Proust, $A$ la recherche du temps perdu. 13. Sodome et Gomorrhe, I922, from Frantext)

\section{CONCLUSION}

The present article has had a double aim: a descriptive and a methodological one. The descriptive aim has been to contribute to existing knowledge of the semantics of one particular French lexeme, the adverb finalement, by way of a comparison with the etymologically and semantically related lexeme enfin.

Both markers have been shown to be polysemous, with enfin having by far the greater range of uses in contemporary French. Interestingly, of the three uses identified for finalement, two turned out to be essentially identical to corresponding uses of enfin, while the third appeared to overlap with a somewhat similar use of enfin in at least some contexts. It was argued, however, that, although some contexts 
are compatible with both, the markers are, in fact, semantically distinct in this third use. Moreover, some evidence was presented for the existence of a division of labour between the two markers, at least in spontaneous spoken speech, such that speakers seem to favour the use of finalement for more 'literal' functions, i.e. for the expression of temporal sequence, whereas enfin is preferred for more abstract, non-propositional functions.

It was argued that this state of affairs could plausibly be attributed to the respective formal properties and degree of grammaticalisation of the two expressions, and that these same properties could also explain why enfin has developed a vastly greater range of abstract, non-propositional functions than finalement. This hypothesis was supported by diachronic evidence that the various functional extensions of enfin have gone hand in hand with significant changes in the formal status of the expression, and that functional extension of finalement essentially stops at approximately the time when enfin begins to expand its range.

The thrust of the methodological argument has been to suggest the relevance of looking more closely at differences in formal properties and in patterns of diachronic evolution when studying the discourse-marking potential of lexical items that are a priori closely related from both a semantic and a pragmatic point of view.

While comparison between synchronic uses of related markers is relatively common in the existing literature thanks, no doubt, to the influence of the structuralist tradition in linguistics, studies of diachronic patterns of similarity and contrast between markers are far rarer. I hope to have shown, however, that such studies may, in fact, both inform and enlighten synchronic descriptions.

Author's address:

Department of English, Germanic, and Romance Studies

University of Copenhagen

Njalsgade 128, build. 24

DK-2300 Copenhagen $S$

Denmark

e-mail:maj@hum.ku.dk

\section{REFERENCES}

Beeching, K. (2002). Gender, Politeness, and Pragmatic Particles in French. Amsterdam: John Benjamins.

Cadiot, A., Ducrot, O., Fradin, B. and Nguyen, T.-B. (1985). Enfin, marqueur métalinguistique. Journal of Pragmatics, 9: 199-239.

Clark, E. V. (1993). The Lexicon in Acquisition. Cambridge: Cambridge University Press.

Ducrot, O. et al. (1980). Les mots du discours. Paris: Editions de Minuit.

Franckel, J.-J. (1989). Etude de quelques marqueurs aspectuels du français. Geneva: Droz.

Geeraerts, D. (1997). Diachronic Prototype Semantics. Oxford: Clarendon Press.

Hansen, A. B. (1998). Les voyelles nasales du français parisien moderne. Aspects linguistiques, sociolinguistiques et perceptuels des changements en cours. Copenhagen: Museum Tusculanum. 
Hansen, M-B. M. (2005). From prepositional phrase to hesitation marker: the semantic and pragmatic evolution of French enfin. Journal of Historical Pragmatics, 6(I): 37-68.

Hopper, P. J. (I99I). On some principles of grammaticalization. In: E. C. Traugott and B. Heine, (eds), Approaches to Grammaticalization, vol. I. Amsterdam: John Benjamins, pp. $17-36$.

Kleiber, G. (1990). La sémantique du prototype. Paris: Presses Universitaires de France.

Labov, W. and Waletzky, J. (I967). Narrative analysis: oral versions of personal experience. In: J. Helm, (ed.), Essays on the Verbal and Visual Arts. Seattle, WA: University of Washington Press (American Ethnological Society), pp. I2-44.

Roulet, E. (1987). Complétude interactive et connecteurs reformulatifs. Cahiers de Linguistique Française, 8: I I I-I 40.

Sacks, H. (1995). Lectures on Conversation, vol. II. Oxford: Blackwell.

Schelling, M. (1982). Quelques modalités de clôture, les conclusifs: finalement, en somme, au fond, de toute façon. Cahiers de Linguistique Française, 4: 63-I05.

Schelling, M. (I983). Remarques sur le rôle de quelques connecteurs (donc, alors, finalement, au fond) dans les enchaînements en dialogue. Cahiers de Linguistique Française, 5: 169-187.

Sweetser, E. (1990). From Etymology to Pragmatics. Cambridge: Cambridge University Press.

Traugott, E. C. and Dasher, R. B. (2002). Regularity in Semantic Change. Cambridge: Cambridge University Press.

Waltereit, R. (To appear). The rise of discourse markers in Italian: a specific type of language change. In: K. Fischer, (ed.), Approaches to Discourse Particles. Amsterdam: Elsevier.

\section{Sources cited}

A propos d'un voyage en Egypte. Conversation recorded and transcribed by Michel Bichard. Université de Paris III. I99I-I992.

Base de français médiéval electronic corpus: http://weblex.ens-lsh.fr/wlx/cgi/ weblex-f?corpus=bfm and CD-ROM concordance by Prévost, S., Heiden, S. and Guillot, C. (2000).

Enguerrand de Monstrelet. Chronique. [I44I]. Ed. L. Douët d'Arcq. Paris: Société de l'Histoire de France. I857-I862.

Frantext electronic corpus: http://atilf.atilf.fr/frantext.htm

Froissart. Chroniques. [ca. I369-I400]. Ed. George T. Diller. Geneva: Droz. (I972).

Rabelais, F. Le tiers livre. [I546]. In: CEuvres complètes, vol. I, ed. P. Jourda. Paris: Classiques Garnier. I962. 